\title{
Chlorine Tolerance and Inactivation of Escherichia coli recovered from Wastewater Treatment Plants in the Eastern Cape, South Africa
}

\author{
Mojisola C. Owoseni ${ }^{1,2, *}$ (D), Ademola O. Olaniran ${ }^{3}$ and Anthony I. Okoh 1,2 \\ 1 SAMRC Microbial Water Quality Monitoring Centre, University of Fort Hare, Alice 5700, South Africa; \\ aokoh@ufh.ac.za \\ 2 Applied and Environmental Microbiology Research Group, Department of Biochemistry and Microbiology, \\ University of Fort Hare, Alice 5700, South Africa \\ 3 Department of Microbiology, School of Life Sciences, University of Kwazulu-Natal, Private Bag X54001, \\ Durban 4000, South Africa; olanirana@ukzn.ac.za \\ * Correspondence: moji.owoseni@gmail.com; Tel.: +27-7193063911
}

Received: 13 June 2017; Accepted: 1 August 2017; Published: 8 August 2017

Featured Application: This study examined the tolerance of Escherichia coli isolates, a fecal indicator of water contamination, to chlorine as a common water disinfectant and the effectiveness of chlorine at different concentrations in eliminating E. coli in wastewater effluent. Data obtained can be used as baseline monitoring data for future epidemiological surveillances that could further enhance the control of $E$. coli and some bacteria species of public health concern in wastewater treatment plants and ensure protection of public and environmental health.

\begin{abstract}
This study investigated the survival of Escherichia coli (E. coli) recovered from secondary effluents of two wastewater treatment plants in the Eastern Cape Province, South Africa, in the presence of different chlorine concentrations. The bacterial survival, chlorine lethal dose and inactivation kinetics at lethal doses were examined. The bacterial isolates were identified by $16 \mathrm{~S}$ rRNA gene sequencing. Comparison of the nucleotide sequences of $16 \mathrm{~S}$ rRNA gene of bacteria with known taxa in the GenBank revealed the bacterial isolates to belong to Escherichia coli. At the recommended free chlorine of $0.5 \mathrm{mg} / \mathrm{L}$, reduction of $E$. coli isolates $(n=20)$ initial bacterial concentration of $8.35-8.75 \log$ was within a range of 3.88-6.0 log at chlorine residuals of $0.14-0.44 \mathrm{mg} / \mathrm{L}$ after $30 \mathrm{~min}$. At higher doses, a marked reduction $(p<0.05)$ in the viability of $E$. coli isolates was achieved with a greater than $7.3 \log$ inactivation of the bacterial population. Inactivation kinetics revealed a high rate of bacterial kill over time $\left(R^{2}>0.9\right)$ at chlorine dose of $1.5 \mathrm{mg} / \mathrm{L}$. This study indicates poor removal of bacteria at free chlorine at $0.5 \mathrm{mg} / \mathrm{L}$ and a greater efficacy of $1.5 \mathrm{mg} / \mathrm{L}$ in checking E. coli tolerance.
\end{abstract}

Keywords: Escherichia coli; chlorine tolerance; chlorine lethal dose; inactivation kinetics; wastewater treatment plants; public health

\section{Introduction}

The growing demand for water for industrial, agricultural, environmental, municipal and domestic requirements has extended the requirements for an improvement in water treatment processes [1]. Water quality is a topical issue in public health due to concerns emanating from the indiscriminate discharge of inadequately treated sewage into water bodies, which is deleterious to human health and the environment [2,3]. The lack of access to good quality water increasingly impaired by the presence of waterborne pathogens continues to be a major contributor to the disease 
burden, morbidity, the retardation of economic growth and the well-being of the populace in many developing countries [4].

The use of an efficient water treatment system that relies on technologically compatible, cost-effective disinfectants that minimizes the production of disinfectant by-products [5] offers a safe margin for wastewater reuse. Commonly used disinfectants for water treatment include ultraviolet (UV) irradiation frequently used in large water and wastewater treatment plants which directly impairs the intracellular functions of microbial cells leading to growth inhibition and death [6]. UV irradiation does not produce disinfectant by-products [7], it is cost-intensive and requires large amounts of energy and frequent maintenance, including replacement of the UV lamps $[8,9]$.

Ozone is highly efficient in the inactivation of viruses, bacteria and protozoa but decomposes rapidly. It also, requires special operation, and potentially forms bromate as a by-product in waters containing bromide $[9,10]$. Chlorine is a potent oxidant which causes the destruction of nucleic acids and cell membranes and it is an attractive option for disinfection due to its ease of handling, low capital cost and production of residual chlorine [11,12]. However, limitations in the use of chlorine include the production of off-tastes and odours, and potential formation of disinfection by-products (DBPs) such as trihalomethanes (THMs), Haloactic acids (HAAs), Haloacetylnitrile (HAN) and nitrosodimethylamine (NDMA) [13-15]. In addition, recovery of chlorine tolerant microbial pathogens at low chlorine dosages has been reported [16-19].

The $C t$ concept (disinfection concentration $C$ multiplied by the contact time $t$ over defined time intervals) has been used to model the effieicncy of many disinfection systems [20-22]. The detailed impact of disinfectant concentrations and exposure times required to sufficiently control microbial pathogens of public health hazards are useful in developing regulations and treatment strategies [6] and have been described by the $C t$ concept. Published data on $C t$ values include 21.7, 18.5 and $52.6 \mathrm{mg} / \mathrm{L} \cdot \mathrm{min}$ free chlorine for $3 \log _{10}$ inactivation of total coliforms, Enterococcus and Salmonella species [23] and 48.99-194.7 $\mathrm{mg} / \mathrm{L} \cdot \mathrm{min}$ free chlorine for strains of Aspergillus and Penicillium [22].

Water regulatory bodies have prescribed guidelines for effluent discharge into water bodies [24]. For example, the South Africa water regulation stipulates a maximum contaminant level (MCL) of zero for total coliforms including E. coli and a residual chlorine concentration of $0.25 \mathrm{mg} / \mathrm{L}$ for effluent discharge into water bodies [25]. Microbiological parameters for routine monitoring of water do not regulate for all pathogens but rather stipulate indicator organisms, including E. coli, that specify a contamination problem with a disinfection step $[1,16,21]$. Strains of $E$. coli such as enterohemorrhagic E. coli O157:H7 have been associated with various outbreaks of waterborne and foodborne diseases such as bloody diarrhoea, haemolytic-uremic syndrome and sometimes death in immune-compromised individuals [26].

Previous studies have demonstrated the susceptibility of E. coli to chlorine. For example, a bench-scale inactivation study examined the inactivation of pathogenic and wild strains E. coli 0157:H7 after $1 \mathrm{~min}$ exposure to $1.1 \mathrm{mg} / \mathrm{L}$ free chlorine and $1.2 \mathrm{mg} / \mathrm{L}$ total chlorine and found significant removal of bacterial strains [27]. Likewise, greater than $99.9 \%$ inactivation of E. coli was achieved at the free chlorine concentration of $0.2 \mathrm{mg} / \mathrm{L}$ at contact time of $0.50 \mathrm{~min}$ [28]. Zhou et al. [29] also reported total sensitivity of bacterial pathogens including E. coli O157:H7 to free chlorine concentrations above $3.66 \mathrm{mg} / \mathrm{L}$ in wash water disinfection process.

However, studies have reported the survival of E. coli survival in chlorinated effluents [30,31]. In the study by [32] the tolerance of E. coli CGMCC to $10 \mathrm{mg} / \mathrm{L}$ chlorine dose was observed with only $4.0 \mathrm{log}$ reduction achieved in a bacterial population of approximately $10^{7}$ colony forming units $(\mathrm{CFU} / \mathrm{mL})$. In South Africa, studies have demonstrated a strong correlation between E. coli survival and low chlorine residuals [33-35]. For example, in the Eastern Cape, South Africa, [36] recovered E. coli strains in wastewater effluents containing low chlorine residuals ranged between 0.05 and $0.24 \mathrm{mg} / \mathrm{L}$. However, there is paucity of information on chlorine tolerance limits and inactivation kinetics of $E$. coli in the Eastern Cape, South Africa thus necessitating the investigation on the efficacy of chlorine in the inactivation of E. coli isolated from secondary effluents of two wastewater treatment 
plants in the Eastern Cape Province, South Africa. Chlorine tolerance limits of E. coli strains were evaluated at varying chlorine concentrations. Data were fitted to Chick-Watson model and Hom model to decscribe inactivation kinetics.

\section{Materials and Methods}

\subsection{Sample Collection and Processing}

Secondary effluent samples were collected from the clarifier of two wastewater treatment plants in the Eastern Cape Province, South Africa and was processed for the isolation of E. coli following standard procedures $[37,38]$ with some modifications. Twenty milliliters of wastewater samples were filtered through sterile cellulose-nitrate membrane filter $(0.45 \mu \mathrm{m}$ pore size, $47 \mathrm{~mm}$ diameter, Millipore filters) under partial vacuum in five replicates. The membrane filters were immediately placed in Petri dishes containing E. coli Chromogenic agar (Conada Pronadisa, Madrid, Spain) with sterile forceps. The agar plates were incubated at $37^{\circ} \mathrm{C}$ for $24 \mathrm{~h}$. After incubation, isolates showing dark blue colonies (typical of E. coli) were recovered, purified and stored in $20 \%$ glycerol at $-80^{\circ} \mathrm{C}$.

\subsection{Preparation of Stock Chlorine Solution}

A stock chlorine solution $(1 \% w / v)$ containing $7000 \mathrm{mg} / \mathrm{L}$ of free chlorine was prepared from calcium hypochlorite granules. This stock solution was diluted to a final free chlorine concentration of $0.5 \mathrm{mg} / \mathrm{L}$ and then quantified by the $N, N$-diethyl- $\rho$-phenylenediamine (DPD) method [38]. The free chlorine concentration was measured using free chlorine kit (Hanna instruments Inc. Woonsocket, RI, USA). The photometer has an accuracy of measurement of $\pm 3 \%$ of reading at $25{ }^{\circ} \mathrm{C}$ and a sensitivity of $0-5.0 \mathrm{mg} / \mathrm{L}$.

\subsection{Molecular Confirmation of Presumptive E. coli Test Isolates}

\subsubsection{DNA Extraction}

The genomic DNA of the presumptive E. coli isolates was extracted by the boiling method as described by $[39,40]$ with modifications. Briefly, previously stored glycerol stocks of E. coli were resuscitated in Tryptic Soy Broth (TSB) at $37^{\circ} \mathrm{C}$ for $24 \mathrm{~h}$. The isolates were then purified and cultured on nutrient agar at $37^{\circ} \mathrm{C}$ for $24 \mathrm{~h}$. Single colonies from presumptive E. coli isolates and a positive control of E. coli (ATCC 3695) were inoculated into $200 \mu \mathrm{L}$ of sterilized distilled water in sterile Eppendorf tubes. Cells were lysed at $100{ }^{\circ} \mathrm{C}$ for $10 \mathrm{~min}$ and centrifuged at 15,000 rpm for $10 \mathrm{~min}$ at $4{ }^{\circ} \mathrm{C}$. The supernatant was collected and stored at $-20^{\circ} \mathrm{C}$ for further use.

\subsubsection{Molecular Identification of Presumptive E. coli Isolates}

The identities of the presumptive E. coli isolates were confirmed by amplification of the uidA gene in combination with the cultural characteristic of the isolate as previously reported by [41]. A reference strain of E. coli ATCC 3695 was used as positive control. The uidA gene amplification was carried out in a final volume of $25 \mu \mathrm{L}$ mixture containing $12 \mu \mathrm{L}$ of TaqMan DNA polymerase Master Mix (New England Biolabs Inc., Ipswich, MA, USA), $6 \mu \mathrm{L}$ of nuclease free water, $1 \mu \mathrm{L}$ of each primer UidA F:5 (AAAACGGCAAGAAAAAGCAG) and uidA R: $5^{\prime}$ (ACGCGTGGTTAACAGTCTTGCG) and $5 \mu \mathrm{L}$ of DNA template. The PCR mixture was subjected to a 5-min denaturation step at $94{ }^{\circ} \mathrm{C}$, followed by 35 cycles of $30 \mathrm{~s}$ at $95{ }^{\circ} \mathrm{C}, 60 \mathrm{~s}$ for $58^{\circ} \mathrm{C}$ and $60 \mathrm{~s}$ at $72{ }^{\circ} \mathrm{C}$ and a final elongation step for $8 \mathrm{~min}$ at $72{ }^{\circ} \mathrm{C}$. The samples were kept at $-20^{\circ} \mathrm{C}$ until analysis. PCR products were confirmed in $1 \%$ Agarose gel electrophoresis in $1 \times$ Tris-Borate-EDTA (TBE) buffer at $100 \mathrm{~V}$ for $60 \mathrm{~min}$, visualized after staining with Ethidium bromide in ALLIANCE 4.7 UV transilluminator and photographed. Thereafter, three E. coli isolates with the highest bacterial counts were sequenced using the $16 \mathrm{~S}$ rRNA gene analysis. The nucleotides sequences were compared to known sequences in the GenBank and were submitted to the 
Basic Local Alignment Search tools (BLAST) search engine at the National Centre for Biotechnological Information (NCBI) GenBank.

\subsection{Bacterial Survival at the Recommended Free Chlorine Concentration $(0.5 \mathrm{mg} / \mathrm{L})$}

A chlorine disinfection assay was carried out for E. coli isolates $(n=20)$ in a bench-scale inactivation study to determine free chlorine residuals and bacterial survival after $30 \mathrm{~min}$ exposure. Prior to the disinfection experiment, the glycerol stock of the isolates was resuscitated in $5 \mathrm{~mL}$ of Tryptic Soy Broth and incubated at $37{ }^{\circ} \mathrm{C}$ for $24 \mathrm{~h}$. Subsequently, a loop of culture streaked on nutrient agar and grown overnight at $37^{\circ} \mathrm{C}$ for $18 \mathrm{~h}$ were aseptically transferred to sterile tubes. Cells were harvested by centrifugation at $6000 \mathrm{~g}$ for $5 \mathrm{~min}$, washed twice with sterilized phosphate buffer (PBS), and re-suspended in sterile PBS at $\mathrm{pH} 7$ and $22{ }^{\circ} \mathrm{C}$ to obtain a concentration of approximately $2.26 \times 10^{8} \mathrm{CFU} / \mathrm{mL}$ as the initial bacterial concentration. Bacterial concentrations in suspensions were measured at an absorbance of $600 \mathrm{~nm}$, using a spectrophotometer (Helios Epsilon, Kinesis Inc., Berlin Township, NJ, USA) and confirmed by plating $0.1 \mathrm{~mL}$ portions of dilutions on E. coli chromogenic agar (Merck). Plates were incubated at $37^{\circ} \mathrm{C}$ for $24 \mathrm{~h}$.

The disinfection experiment was carried out by the addition of Calcium hypochlorite $(1 \% w / v)$ containing $0.5 \mathrm{mg} / \mathrm{L}$ free chlorine to $100 \mathrm{~mL}$ of PBS containing E. coli isolates in $250 \mathrm{~mL}$ sterile bottles at $\mathrm{pH} 7.0$ and $22{ }^{\circ} \mathrm{C}$ for $30 \mathrm{~min}$. The reaction mixture was stirred continuously at $160 \mathrm{rpm}$ on a magnetic stir plate. After $30 \mathrm{~min}$, duplicates of $10 \mathrm{~mL}$ of treated bacterial suspensions were withdrawn and analysed for the residual chlorine concentration by the DPD method [38]. Chlorine residues were neutralized by the addition of $25 \mu \mathrm{L}$ sodium thiosulfate ( $3 \% w / v)$. After series of dilutions, triplicates of one hundred microliters from the final dilutions were spread on E. coli chromogenic agar and plates were incubated at $37^{\circ} \mathrm{C}$ for $24 \mathrm{~h}$. A disinfection assay was repeated twice for each set of experimental conditions and triplicates samples of untreated water were processed as disinfection control.

\subsection{Determination of Lethal Dose of Chlorine}

The disinfection efficacy at higher doses of chlorine was assessed against three E. coli isolates following the method described by [28]. Three E. coli isolates, E. coli SAMRC-1, E. coli SAMRC-2, E. coli SAMRC-3 were selected based on the high bacterial survival at $0.5 \mathrm{mg} / \mathrm{L}$ chlorine concentration. At initial bacterial concentration of approximately 1.6-1.7 $\times 10^{8} \mathrm{CFU} / \mathrm{mL}$, Calcium hypochlorite $(1 \% w / v)$ was added to $100 \mathrm{~mL}$ of $0.1 \mathrm{M}$ phosphate-buffered suspension of $E$. coli isolates contained in $250 \mathrm{~mL}$ sterile bottles at $\mathrm{pH} 7$ and at $22^{\circ} \mathrm{C}$ to achieve chlorine concentrations ranging between 0.75 and $1.5 \mathrm{mg} / \mathrm{L}$. The mixture was stirred continuously at $160 \mathrm{rpm}$ on a magnetic stir plate for $30 \mathrm{~min}$. After 30 min exposure, the reaction was immediately terminated by the addition of sodium thiosulfate $(3 \% w / v)$. After a series of dilutions of the treated suspension, triplicates of one hundred microliters of the final dilution were transferred to $E$. coli Chromogenic agar and incubated at $37^{\circ} \mathrm{C}$ for $24 \mathrm{~h}$. The means of residual chlorine concentrations were also determined in duplicates and the disinfection assay was repeated twice.

\subsection{Inactivation Kinetics of E. coli Isolates}

Inactivation kinetics was carried out by subjecting the E. coli isolates to chlorine lethal dose of $1.5 \mathrm{mg} / \mathrm{L}$ at intervals of $10 \mathrm{~min}$ over $30 \mathrm{~min}$ exposure. At an initial bacterial concentration of approximately $1.6-1.7 \times 10^{8} \mathrm{CFU} / \mathrm{mL}$, thirty-seven microliters of $1 \%(w / v)$ Calcium hypochlorite was added to $100 \mathrm{~mL}$ of bacterial suspension. The mixture was continuously stirred at $160 \mathrm{rpm}$ on a magnetic stir plate for $30 \mathrm{~min}$. At intervals of $10 \mathrm{~min}$, aliquots of $10 \mathrm{~mL}$ were withdrawn from the mixture and analysed for a residual chlorine concentration. Aliquots were also withdrawn from the mixture at $10 \mathrm{~min}$ interval and instantaneously neutralized by the addition of $3 \% w / v$ sodium thiosulfate. An enumeration of the bacteria was carried out by spreading one hundred microliters of the final dilution of each isolate on E. coli chromogenic agar and plates which were incubated at $37^{\circ} \mathrm{C}$ 
for $24 \mathrm{~h}$. Residual chlorine concentrations were determined in duplicates while bacterial survival was carried out in triplicates.

\subsection{Data Analysis}

The removal efficiency by the chlorine concentrations were expressed as $\log _{10}$ reduction of bacterial population as described by [42]:

$$
\mathrm{LR}=\log _{10}\left(N_{t} / N_{0}\right)
$$

$\mathrm{LR}=\log$ reduction of bacteria count at time $t ; N_{0}=$ initial bacterial concentration at time $0, N_{t}=$ final bacterial concentrations after a treatment time $t$.

The disinfection kinetic parameters of $E$. coli at higher chlorine concentrations were determined by fitting inactivation data to the Chick-Watson empirical model [43]. The empirical logarithm equation was expressed as:

$$
\log \left(N / N_{0}\right)=-k C^{\mathrm{n}} T
$$

where, $N=$ bacterial concentration at time $t, N_{0}=$ initial bacterial concentration at time $0, C=$ free chlorine concentration $(\mathrm{mg} / \mathrm{L}), T=$ contact time $(\mathrm{min}), k=$ inactivation rate constant, $n=$ coefficient of dilution.

For log reduction/time plots for survivors, inactivation data was fitted to the empirical model of $[43,44]$. Data were $\log _{10}$ transformed and statistical analysis was performed by linear regression using Origin Pro 2017.

The Hom model is expressed as:

$$
\log \left(N / N_{0}\right)=-k C^{n} T^{m}
$$

where $N=$ bacterial concentration at time $t, N_{0}=$ initial bacterial concentration at time $0, C=$ residual free chlorine concentration $(\mathrm{mg} / \mathrm{L})$ at time $t, T=$ contact time $(\mathrm{min}), k=$ inactivation rate constant, $n=$ chlorine exponent (Hom model), $m=$ time exponent

Using multiple linear regression analysis, the constants were evaluated as:

$$
\log \left(N / N_{0}\right)=\log k+n \log C+m \log
$$

Statistically significant differences were determined between untreated and chlorine treated E. coli strains. Statistically significant differences in inactivation were also determined among the chlorine treated E. coli strains by one-way analysis of variance (ANOVA) and Turkey Post Hoc comparison test using SPSS (IBMSPSS Statistics 23). Differences between means were considered significant at $p<0.05$.

\section{Results}

\subsection{Molecular Confirmation of Presumptive E. coli Isolates}

Molecular identification showed the presumptive bacterial isolates to belong to E. coli. The three isolates with the highest chlorine tolerant profiles were identified by $16 \mathrm{~S}$ ribosomal RNA gene sequencing and BLAST results revealed them to have $99 \%$ similarities to E. coli. The nucleotide sequences of the three E. coli isolates were deposited in GenBank as E. coli SAMRC-1 (accession number KX874327), E. coli SAMRC-2 (accession number KX874328) and E. coli SAMRC-3 (accession number KX874329).

\subsection{Bacterial Survival at Free Chlorine Concentration of $0.5 \mathrm{mg} / \mathrm{L}$ for $30 \mathrm{~min}$}

Table 1 shows results of bacterial reductions and free chlorine residuals obtained from E. coli suspensions $(n=20)$ after initial screening at $0.5 \mathrm{mg} / \mathrm{L}$ chlorine concentration. 
Table 1. Bactericidal activity and residual chlorine at free chlorine concentration of $0.5 \mathrm{mg} / \mathrm{L}$ on E. coli isolates for $30 \mathrm{~min}$.

\begin{tabular}{cccc}
\hline Bacterial Isolates & $\begin{array}{c}\text { Surviving Population } \\
\text { (CFU/mL) }\end{array}$ & $\begin{array}{c}\text { Log Reduction } \mathbf{l o g}_{\mathbf{1 0}} \\
\text { CFU/mL) }\end{array}$ & $\begin{array}{c}\text { Residual Chlorine } \\
\text { (mg/L) }\end{array}$ \\
\hline AEC1 & $3.0 \pm 0.14 \times 10^{3}$ & 4.88 & $0.29 \pm 0.01$ \\
AEC8 & $4.0 \pm 0.36 \times 10^{3}$ & 5.75 & $0.39 \pm 0.01$ \\
AEC11 & $1.70 \pm 2.6 \times 10^{3}$ & 5.12 & $0.41 \pm 0.01$ \\
AEC14 & $3.10 \pm 1.6 \times 10^{3}$ & 4.86 & $0.35 \pm 0.01$ \\
AEC16 & $1.10 \pm 1.3 \times 10^{3}$ & 5.3 & $0.33 \pm 0.04$ \\
E. coli SAMRC-1 & $3.23 \pm 0.55 \times 10^{3}$ & 4.84 & $0.44 \pm 0.01$ \\
AEC17 & $1.0 \pm 0.1 \times 10^{3}$ & 5.75 & $0.36 \pm 0.01$ \\
AEC18 & $3.30 \pm 0.06 \times 10^{3}$ & 6.0 & $0.34 \pm 0.01$ \\
AEC24 & $3.17 \pm 0.12 \times 10^{3}$ & 5.04 & $0.35 \pm 0.01$ \\
DEC 2 & $3.00 \pm 0.2 \times 10^{3}$ & 4.88 & $0.41 \pm 0.01$ \\
DEC3 & $3.3 \pm 0.21 \times 10^{3}$ & 5.04 & $0.35 \pm 0.01$ \\
DEC4 & $3.0 \pm 0.17 \times 10^{3}$ & 4.88 & $0.42 \pm 0.02$ \\
DEC12 & $4.0 \pm 0.1 \times 10^{3}$ & 5.0 & $0.41 \pm 0.01$ \\
DEC 18 & $2.67 \pm 0.3 \times 10^{3}$ & 4.93 & $0.42 \pm 0.04$ \\
DEC 19 & $2.50 \pm 0.3 \times 10^{3}$ & 5.0 & $0.31 \pm 0.01$ \\
DEC 20 & $2.5 \pm 0.2 \times 10^{3}$ & 5.0 & $0.42 \pm 0.01$ \\
DEC 23 & $5.67 \pm 0.31 \times 10^{3}$ & 5.0 & $0.39 \pm 0.01$ \\
DEC 26 & $5.5 \pm 0.21 \times 10^{3}$ & 5.0 & $0.40 \pm 0.01$ \\
E. coli SAMRC-2 & $9.67 \pm 6.03 \times 10^{3}$ & 4.37 & $0.37 \pm 0.01$ \\
E. coli SAMRC-3 & $3.03 \pm 1.8 \times 10^{4}$ & 3.88 & $0.42 \pm 0.04$ \\
\hline
\end{tabular}

AEC: $E$. coli isolates recovered from wastewater treatment plant A; DEC: E. coli isolates recovered from wastewater treatment plant $\mathrm{B}, n=20$.

At initial bacterial concentration of 8.5-8.8 log, bacterial reductions ranged from 3.88-6.0 log after $30 \mathrm{~min}$ and residual chlorine concentrations were $0.29-0.44 \mathrm{mg} / \mathrm{L}$. The lowest bacterial reductions were observed for three strains of E. coli (E. coli SAMRC-1, E. coli SAMRC-2 and E. coli SAMRC-3) at $4.84 \log \left(3.23 \times 10^{3} \mathrm{CFU} / \mathrm{mL}\right), 4.37 \log \left(9.67 \times 10^{3} \mathrm{CFU} / \mathrm{mL}\right)$ and $3.87 \log \left(3.03 \times 10^{4} \mathrm{CFU} / \mathrm{mL}\right)$, respectively. Although residual chlorine concentrations were high and within the recommended free chlorine of $0.25 \mathrm{mg} / \mathrm{L}$ free chlorine for South African wastewater effluent discharge [25], many isolates still showed high bacterial counts at these chlorine concentrations. The poor removal efficiency of $0.5 \mathrm{mg} / \mathrm{L}$ in eliminating E. coli suggests tolerance of the bacteria to $0.5 \mathrm{mg} / \mathrm{L}$ chlorine concentration. In a related study, poor removal efficiency of $0.5 \mathrm{mg} / \mathrm{L}$ free chlorine was observed for Citrobacter sp. where only $4-5 \log$ reduction (initial bacterial population of $8.2 \mathrm{log}$ ) was achieved in chlorinated bacterial suspension [19]. Another study also reported recovery of high counts of E. coli ranging between 1.24 and $4.95 \log _{10} \mathrm{CFU} / \mathrm{mL}$ in wastewater effluent samples containing chlorine residuals of 0.24-0.44 mg/L [45]. Similarly, [42] also documented significant regrowth and reactivation of E. coli and Salmonella species in reclaimed water samples with chlorine levels of 0.2 and $0.5 \mathrm{mg} / \mathrm{L}$ thus indicating the inefficiency of $0.5 \mathrm{mg} / \mathrm{L}$ chlorine dosing in removing E. coli as observed in this study.

The recommended $C t$ values for chlorination corresponds to $15 \mathrm{mg} / \mathrm{L} \cdot \mathrm{min}$ at $\mathrm{pH}$ of less than 7.5 and temperature above $10{ }^{\circ} \mathrm{C}[21,29,46]$. In this study, a $C t$ value of $15 \mathrm{mg} / \mathrm{L} \cdot \mathrm{min}$ achieved 3-4 log inactivation of $E$. coli at $\mathrm{pH} 7.0$ and $22^{\circ} \mathrm{C}$. However, this $C t$ value was lower than the $C t$ value obtained from a previous study by [23] where $C t$ for 3-log inactivation for total coliforms was estimated at $21.7 \mathrm{mg} / \mathrm{L} \cdot \mathrm{min}$. The differences in the $C t$ values may be due to reclaimed water samples used for chlorine disinfection compared to chlorine demand-free water used in this study.

The survival of the test $E$. coli isolates at the recommended free chlorine concentration of $0.5 \mathrm{mg} / \mathrm{L}$ indicates a compromise of water quality as the survival of $E$. coli in chlorine treated water signifies the existence of other microbial pathogens [21] and is a threat to public health and environmental safety. 


\subsection{Effect of Lethal Dose of Chlorine on E. coli Survival}

To investigate the efficacy of increasing chlorine doses on the inactivation of the test $E$. coli isolates, three E. coli strains in suspensions (initial bacterial concentration of 8.2-8.23 log) were exposed to chlorine concentrations of $0.75-1.5 \mathrm{mg} / \mathrm{L}$ for $30 \mathrm{~min}$. The survival of the three $E$. coli isolates at higher free chlorine concentrations were compared with survival at $0.5 \mathrm{mg} / \mathrm{L}$ (Figure 1).

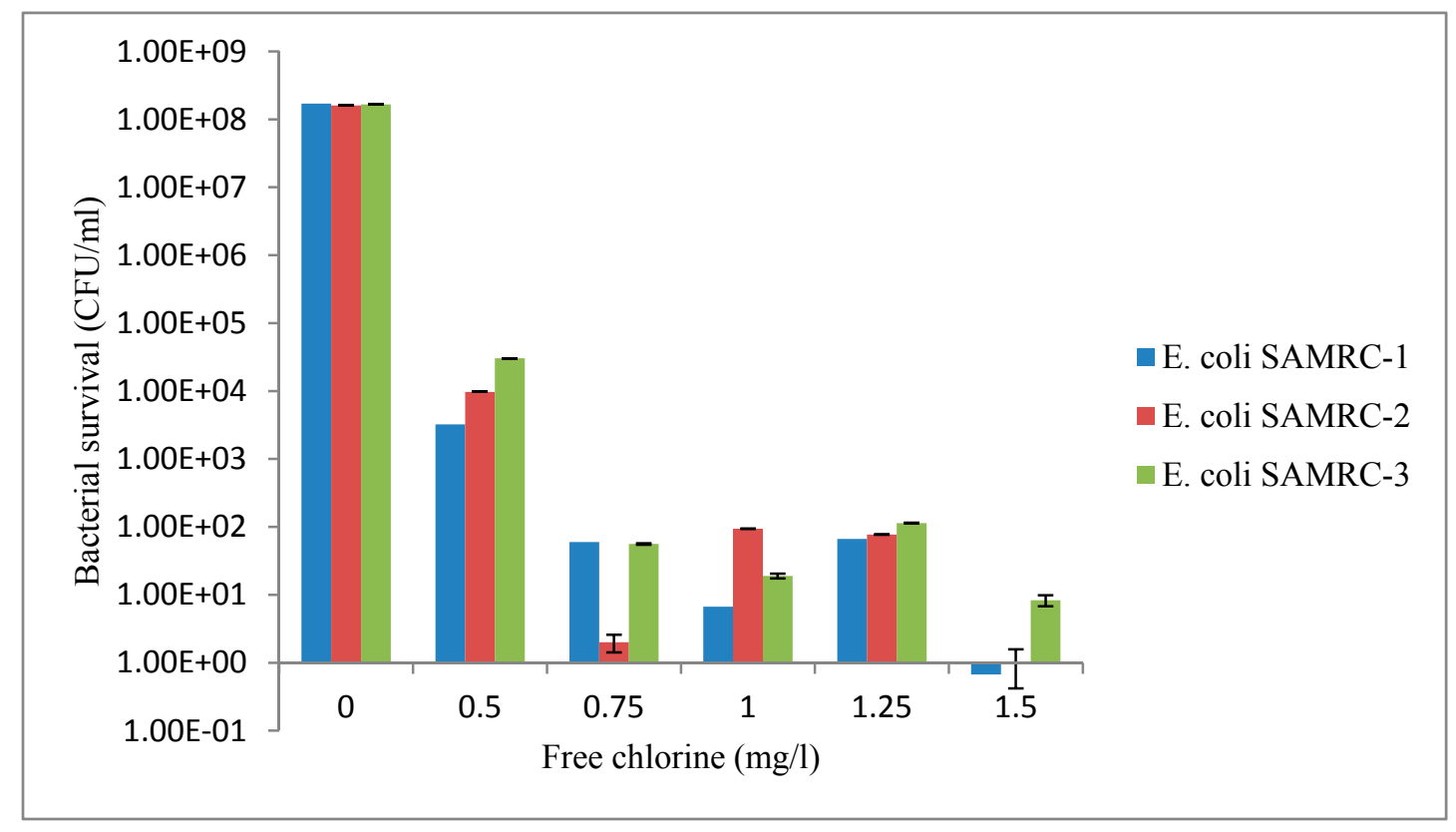

Figure 1. Reduction of E. coli at free chlorine concentrations at $0.5-1.5 \mathrm{mg} / \mathrm{L}$ for $30 \mathrm{~min}$. Error bars represent standard deviation from the mean, $n=5$.

At $0.75-1.25 \mathrm{mg} / \mathrm{L}$ free chlorine, the removal efficiency of E. coli SAMRC-1 was $6.41-6.45 \mathrm{log}$ and virtually $100 \%$ inactivation was achieved at free chlorine concentration of $1.5 \mathrm{mg} / \mathrm{L}$ within $30 \mathrm{~min}$ at residual chlorine concentrations of $(0.29 \pm 0.02)-(0.9 \pm 0.05) \mathrm{mg} / \mathrm{L}$. In comparison, chlorine concentration of $0.5 \mathrm{mg} / \mathrm{L}$ achieved the lowest $\log$ removal of $4.1 \mathrm{log}$. For E. coli SAMRC-2, a removal efficiency of 6.2-7.9 $\mathrm{log}$ was achieved at $0.75-1.25 \mathrm{mg} / \mathrm{L}$ free chlorine and complete inactivation of the E. coli population at chlorine concentration of $1.5 \mathrm{mg} / \mathrm{L}$ at residual chlorine concentrations of $(0.55 \pm 0.05)-(1.23 \pm 0.04) \mathrm{mg} / \mathrm{L}$. In contrast, chlorine concentration of $0.5 \mathrm{mg} / \mathrm{L}$ showed a lower removal efficiency of $4.2 \mathrm{log}$. The removal efficiency for E. coli SAMRC-3 ranged between 6.2 and $6.9 \mathrm{log}$ at chlorine concentrations of $0.75-1.25 \mathrm{mg} / \mathrm{L}$ while the highest removal of $7.3 \mathrm{log}$ units was achieved at chlorine concentration of $1.5 \mathrm{mg} / \mathrm{L}$. Residual chlorine concentrations after $30 \mathrm{~min}$ were $(0.42 \pm 0.08)-(1.22 \pm 0.01) \mathrm{mg} / \mathrm{L}$. In contrast, $0.5 \mathrm{mg} / \mathrm{L}$ achieved disinfection efficiency of $3.7 \mathrm{log}$.

Water guidelines recommend a maximum contaminant level (MCL) of zero for total coliforms including E. coli for effluent discharge into water bodies [26] and a greater removal efficiency of E. coli isolates was achieved at higher chlorine doses of $0.75-1.5 \mathrm{mg} / \mathrm{L}$ compared to log inactivation at $0.5 \mathrm{mg} / \mathrm{L}$ in $30 \mathrm{~min}$. This might be due to the presence of higher chlorine species reacting with bacteria cells which causes greater inactivation of bacteria. It has been hypothesized that solutions with higher oxidizing species have higher oxidation potential to inactivate bacteria [28].

A study also reported greater than $5 \mathrm{log}$ reductions of Shiga-toxigenic E. coli serotypes 026 and 0103 after treatment with a chlorine dose of $1.0 \mathrm{mg} / \mathrm{L}$ in $5 \mathrm{~min}$ [47]. High sensitivity of E. coli O157:H7 and Listeria monocytogenes to free chlorine concentrations equal to or higher than $1.0 \mathrm{mg} / \mathrm{L}$ was recorded with no detection of bacteria after chlorine treatment [48]. The Minimum Inhibitory Concentration (MIC) of planktonic bacterial isolates was also achieved at free chlorine concentrations ranging between 1.0 and $2.0 \mathrm{mg} / \mathrm{L}$ [16]. Low percentages of intact cells of coliforms and E. coli were found 
in drinking water samples after treatment with free chlorine concentrations above $0.5 \mathrm{mg} / \mathrm{L}$, while higher percentages of intact cells were observed at free chlorine concentrations below $0.5 \mathrm{mg} / \mathrm{L}$ [49].

The difference between the control and chlorine treated E. coli strains was not statistically significant $(p<0.05)$ at all the treatment levels and there were no statistically significant differences $(p<0.05$ in inactivation among the chlorine treated E. coli isolates at $0.75-1.5 \mathrm{mg} / \mathrm{L}$. However, a chlorine concentration of $1.5 \mathrm{mg} / \mathrm{L}$ was found to be optimal for E. coli inactivation.

\subsection{Inactivation of E. coli at Free Chlorine Dose of $1.5 \mathrm{mg} / \mathrm{L}$ after $30 \mathrm{~min}$ Exposure}

The inactivation of the three E. coli strains initial bacterial density of approximately $8.2 \log$ by chlorine disinfectant was assessed at the initial chlorine concentration of $1.5 \mathrm{mg} / \mathrm{L}$. Bacterial survival was progressively monitored at $10 \mathrm{~min}$ interval over $30 \mathrm{~min}$ exposure (Figures 2-4).

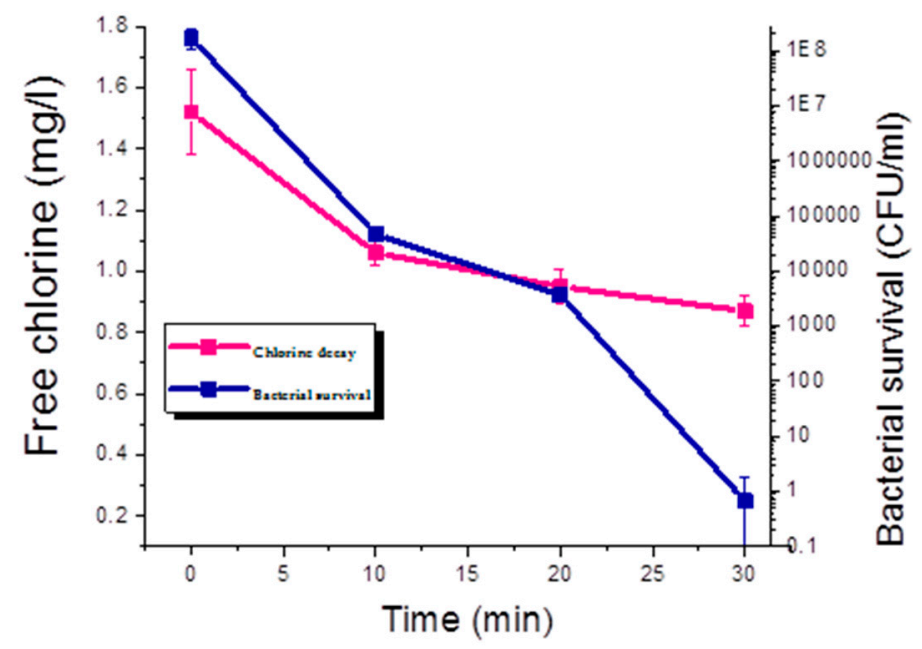

Figure 2. Chlorine decay and inactivation of E. coli SAMRC-1 at $1.5 \mathrm{mg} / \mathrm{L}$ during $30 \mathrm{~min}$ exposure. Bacterial survival and chlorine decay were quantified at $10 \mathrm{~min}$ interval. The error bars represent standard deviation from the mean, $n=3$.

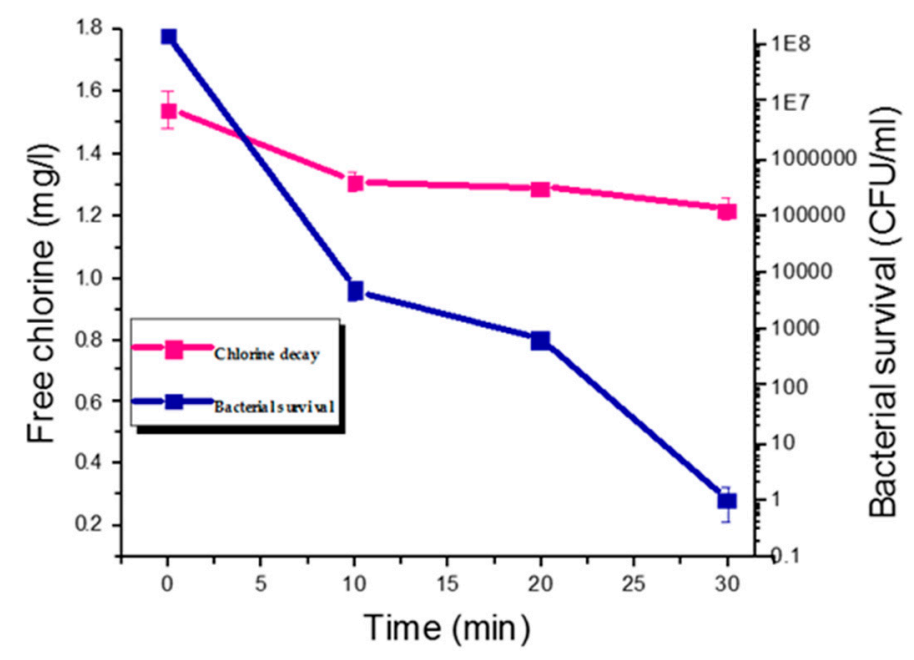

Figure 3. Chlorine decay and inactivation of E. coli SAMRC-2 at $1.5 \mathrm{mg} / \mathrm{L}$ during $30 \mathrm{~min}$ exposure. Bacterial survival and chlorine decay were quantified at $10 \mathrm{~min}$ interval. The error bars represent standard deviation from the mean, $n=3$. 


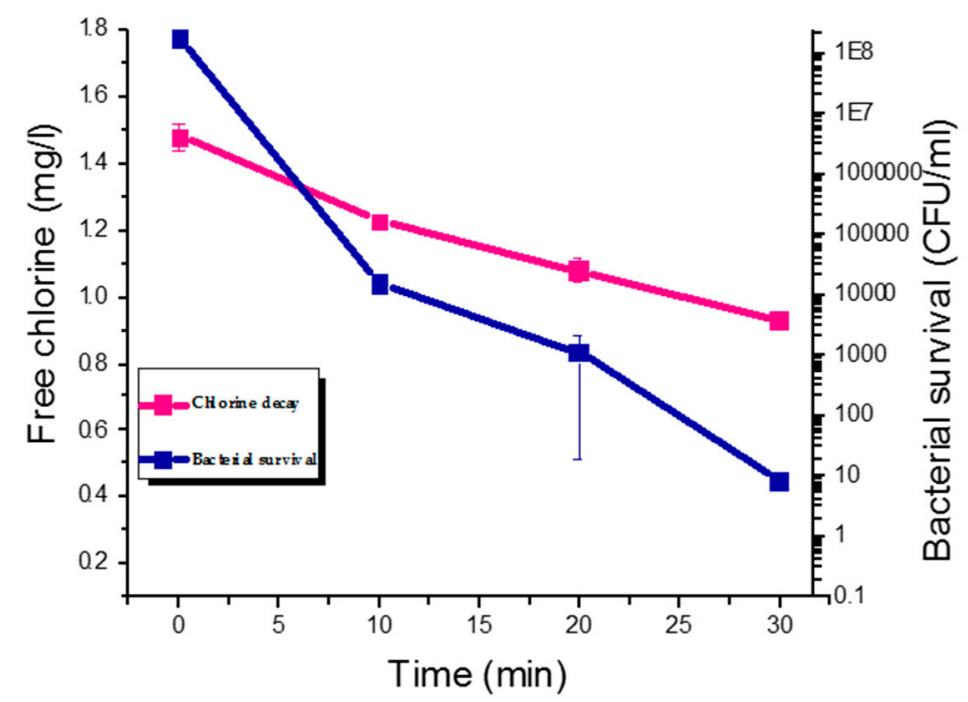

Figure 4. Chlorine decay and inactivation of E. coli SAMRC-3 at $1.5 \mathrm{mg} / \mathrm{L}$ during $30 \mathrm{~min}$ exposure. Bacterial survival and chlorine decay were quantified at $10 \mathrm{~min}$ interval. The error bars represent standard deviation from the mean, $n=3$.

At $1.5 \mathrm{mg} / \mathrm{L}$ chlorine concentration for $30 \mathrm{~min}$, viable counts of $E$. coli SAMRC-1 were reduced to $3.6 \log \left(4.67 \times 10^{4} \mathrm{CFU} / \mathrm{mL}\right)$ in $10 \mathrm{~min}, 4.7 \log \left(3.67 \times 10^{3} \mathrm{CFU} / \mathrm{mL}\right)$ in $20 \mathrm{~min}$ and complete inactivation of E. coli in $30 \mathrm{~min}$ (Figure 2). A reduction in viable counts of E. coli SAMRC-2 was $4.51 \mathrm{log}$ $\left(5.0 \times 10^{3} \mathrm{CFU} / \mathrm{mL}\right)$ in $10 \mathrm{~min}, 5.38 \log \left(6.67 \times 10^{2} \mathrm{CFU} / \mathrm{mL}\right)$ in $20 \mathrm{~min}$ and complete inactivation was achieved in $30 \mathrm{~min}$ (Figure 3) while E. coli SAMRC-3 was reduced to $4.04 \log \left(1.53 \times 10^{4} \mathrm{CFU} / \mathrm{mL}\right)$ in $10 \mathrm{~min}, 5.19 \log \left(1.07 \times 10^{3} \mathrm{CFU} / \mathrm{mL}\right)$ in $20 \mathrm{~min}$ and $7.3 \log (8.3 \mathrm{CFU} / \mathrm{mL})$ in $30 \mathrm{~min}$ (Figure 4).

Bacterial inactivation was rapid within the first $10 \mathrm{~min}$ while inactivation rate slowly declined afterwards with increase in contact time. Previous studies have shown that the highest reduction of bacterial population occurred within 10-15 min of exposure [50,51].

A tailing-off effect observed for E. coli strains is shown in Figure 2. The tailing-off implies a shielding phenomenon in which a certain portion of the bacterial population, after inactivation by chlorine, returns the bacteria suspension into its initial state, but with a lower number of viable cells. Further reaction between the chlorine species and bacteria then results in inactivation of smaller portions of viable bacteria due to shielding by previously inactivated cells [52]. Similar observations of tailing-off effects have been reported in some inactivation experiments. For example, Winward et. al. [53] reported a tailing phase for total coliforms in raw grey water treated with 1-5 mg/L free chlorine for $120 \mathrm{~min}$. Similarly, Van Haute et. al. [54] reported a tailing-off for $E$. coli $\mathrm{O} 157$ in the chlorine-demand free buffer and [55] observed a tailing-off in the inactivation curve of Enterococcus sp. treated with $90 \mathrm{mg} \mathrm{O} / \mathrm{L}$ of ozone.

An estimation of $\mathrm{Ct}$ values for 7-log inactivation of $E$. coli extrapolated from the linear regression lines showed 41.1, 42.4 and $49.9 \mathrm{mg} / \mathrm{L} \cdot \mathrm{min}$ free chlorine for E. coli SAMRC-1, E. coli SAMRC-2 and E. coli SAMRC-3, respectively (Figure 5). 


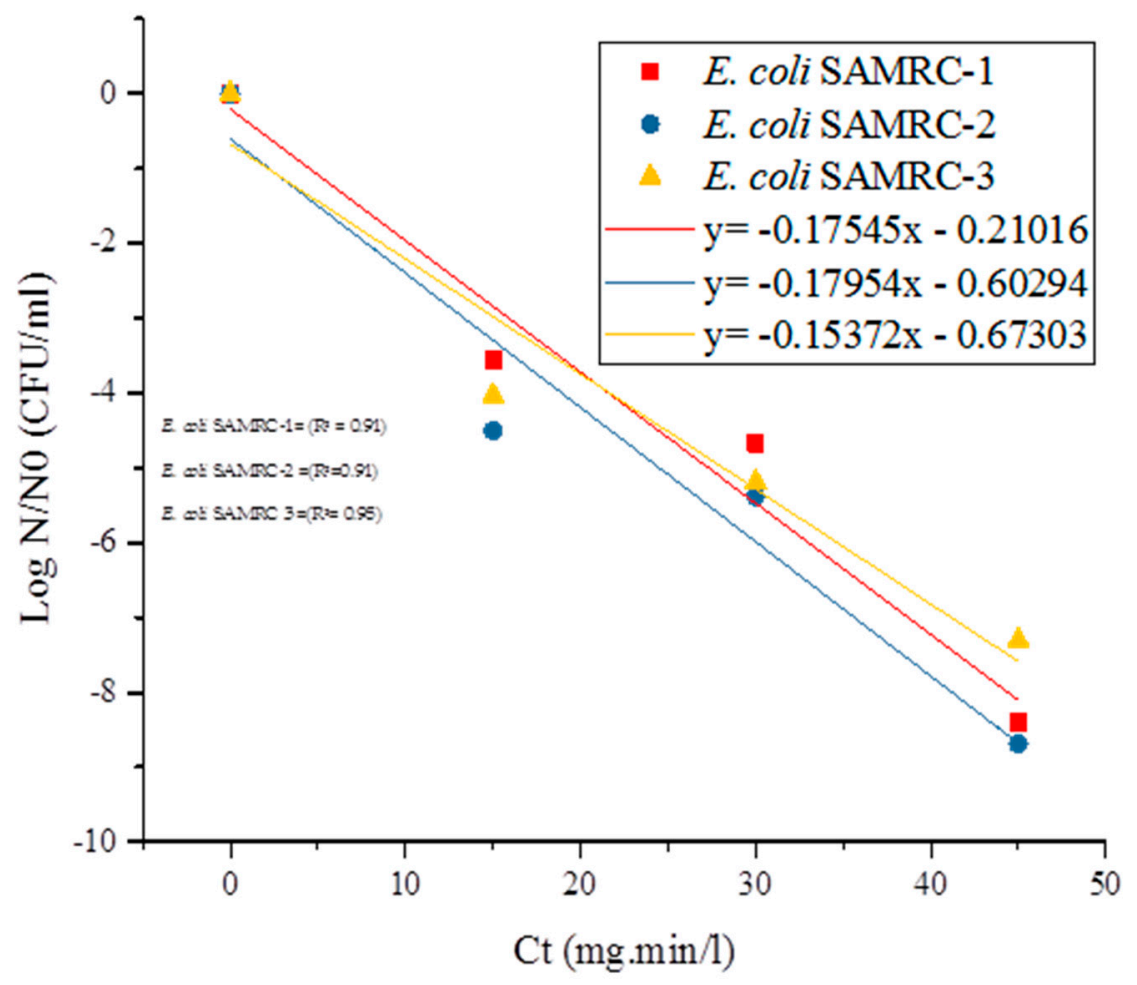

Figure 5. Chlorine inactivation of $E$. coli at free chlorine concentration of $1.5 \mathrm{mg} / \mathrm{L}$ at $30 \mathrm{~min}$ exposure $\left(\mathrm{pH}=7\right.$, temperature $\left.=22^{\circ} \mathrm{C}\right), n=3$.

These $C t$ values were higher than compared to the $C t$ values for 7 log inactivation of $E$. coli by free chlorine obtained in previous studies. For example, Zhao et al. [56] observed greater than 7-log inactivation of $E$. coli O157:H7 at a $C t$ value of $0.25 \mathrm{mg} / \mathrm{L} \cdot \mathrm{min}$. The differences in inactivation may be due to higher initial bacterial density $\left(10^{8} \mathrm{CFU} / \mathrm{mL}\right)$ of $E$. coli used in this study compared to initial bacterial density $\left(10^{6} \mathrm{CFU} / \mathrm{mL}\right)$ used in the previous study.

\subsection{Inactivation Kinetics of Bacteria by Chlorine at 30 min Contact Time}

In order to evaluate the kinetics of $E$. coli inactivation at higher chlorine concentrations (0.75-1.5 mg/L) after 30 min exposure, inactivation data were fitted to the Chick-Watson empirical model (Table 2) to determine disinfection kinetic parameters, $R^{2}$ (coefficient of determination), inactivation rate constant, $k$, and coefficient of dilution, $n$.

Table 2. Inactivation kinetics of $E$. coli at chlorine concentrations of $0.75-1.5 \mathrm{mg} / \mathrm{L}$ for $30 \mathrm{~min}$ (Chic-Watson model: $\log N / N_{0}=-k C^{n} T$ ).

\begin{tabular}{lcccc}
\hline \multirow{2}{*}{ Bacterial Strains } & \multicolumn{4}{c}{ Free Chlorine (mg/L) } \\
\cline { 2 - 5 } & $\boldsymbol{R}^{\mathbf{2}}$ & $\boldsymbol{k}$ & $\boldsymbol{n}$ & $\boldsymbol{p}$ \\
\hline E. coli SAMRC-1 & 0.64 & $-1.99 \pm 1.43$ & $-4.66 \pm 1.47$ & 0.03 \\
E. coli SAMRC-2 & 0.71 & $-1.33 \pm 1.36$ & $-5.07 \pm 1.40$ & 0.02 \\
E. coli SAMRC-3 & 0.77 & $-1.21 \pm 1.08$ & $-4.67 \pm 1.12$ & 0.01 \\
\hline
\end{tabular}

$R^{2}$ : coefficient of determination; $k$ : inactivation rate constant; $n$ : coefficient of dilution; $P$ : probability level of $k$ values (considered significant at $p<0.05), n=3$.

From the linear regression, $R^{2}$ values ranged between 0.64 and 0.77 . Significant differences $(p<0.5)$ in inactivation rate constant $k$ were observed for each tested $E$. coli strain at $-1.99 \pm 1.43,-1.33 \pm 1.36$ and $-1.21 \pm 0.08 \mathrm{mg} / \mathrm{L}$ for E. coli SAMRC-1, E. coli SAMRC-2 and E. coli SAMRC-3, respectively. The 
inactivation rate constant $k$, describes the sensitivity of bacteria to inactivation by disinfectants [57]. The highest inactivation rate constant $k(-1.99 \pm 1.43 \mathrm{mg} / \mathrm{L})$ observed for $E$. coli SAMRC-1 suggests higher sensitivity of E. coli SAMRC-1 to free chlorine while E. coli SAMRC-3 with the lowest value of $k$, reflects a more resistant bacterial population to free chlorine. The coefficient of dilution, $n$ values were 4.66, 5.07 and 4.67 for E. coli SAMRC-1, E. coli SAMRC-2 and E. coli SAMRC-3, respectively. Differences in $n$ represent the average number of disinfectant molecules in contact with an organism available to cause inactivation [58] and this was reflected in the increased inactivation for E. coli SAMRC-2 (higher value of $n=5.07$ ) compared to the other $E$. coli strains. Variations in $n$ indicate physiological differences between organisms, inactivation conditions and availability of nutrients in the cultivation media [58]. Difference in the values of $k$ and $n$ for two strains of E. coli, K12 and 0157:H7 exposed to chlorine concentrations of $0.1-8.0 \mathrm{mg} / \mathrm{L}$ for $10 \mathrm{~min}$ have been reported [59].

Inactivation kinetics of $E$. coli at optimal chlorine dose of $1.5 \mathrm{mg} / \mathrm{L}$ at intervals of $10 \mathrm{~min}$ over 30 min exposure were evaluated using the Chick-Watson (Table 3) and Hom model (Table 4) model.

Table 3. Inactivation kinetics of E. coli at chlorine concentrations of $1.5 \mathrm{mg} / \mathrm{L}$ (Chick-Watson model: $\left.\log N / N_{0}=-k C^{n} T\right)$.

\begin{tabular}{lcccc}
\hline \multirow{2}{*}{ Bacterial Strains } & \multicolumn{4}{c}{ Free Chlorine (mg/L) } \\
\cline { 2 - 5 } & $\boldsymbol{R}^{\mathbf{2}}$ & $\boldsymbol{k}$ & $\boldsymbol{n}$ & $\boldsymbol{p}$ \\
\hline E. coli SAMRC-1 & 0.95 & $-0.21 \pm 0.68$ & $-0.26 \pm 0.04$ & 0.02 \\
E. coli SAMRC-2 & 0.91 & $-0.60 \pm 0.88$ & $-0.27 \pm 0.05$ & 0.03 \\
E. coli SAMRC-3 & 0.91 & $-0.67 \pm 0.76$ & $-0.23 \pm 0.04$ & 0.03 \\
\hline
\end{tabular}

$R^{2}:$ coefficient of determination; $k$ : inactivation rate constant; $n$ : coefficient of dilution; $P$ : probability level of $k$ values (considered significant at $p<0.05$ ), $n=3$.

Table 4. Inactivation of $E$. coli as a function of chlorine dose $(1.5 \mathrm{mg} / \mathrm{L})$ and contact time (30 $\mathrm{min})$ (Hom model: $\left.\log \left(N / N_{0}\right)=-k^{n} T^{m}\right)$.

\begin{tabular}{lcccccc}
\hline \multirow{2}{*}{ Bacterial Strains } & \multirow{2}{*}{$\boldsymbol{R}^{\mathbf{2}}$} & $\boldsymbol{k}$ & \multicolumn{2}{c}{ Chlorine Exponent } & \multicolumn{2}{c}{ Time Exponent } \\
\cline { 4 - 7 } & & & $\boldsymbol{n}$ & $\boldsymbol{p}$ & $\boldsymbol{m}$ & $\boldsymbol{p}$ \\
\hline E. coli SAMRC-1 & 0.90 & -2.42 & 1.57 & 0.80 & -0.23 & 0.31 \\
E. coli SAMRC-2 & 0.96 & -19.88 & 12.96 & 0.34 & -0.14 & 0.33 \\
E. coli SAMRC-3 & 0.98 & -33.2 & 22.4 & 0.20 & 0.17 & 0.41 \\
\hline
\end{tabular}

$R^{2}$ : coefficient of determination; $k$ : inactivation rate constant; $n$ : disinfection exponent; $m$ : time exponent; $p$ : probability level. All disinfection parameters were considered significant at $p<0.05, n=3$.

Comparatively, the Hom model gave a good fit for inactivation of $E$. coli by chlorine disinfectant with $R^{2}$ values ranging from 0.9 to 0.98 while Chick-Watson model showed with $R^{2}$ values of $0.91-0.95$. Overall, these results indicate a strong correlation between bacterial inactivation and chlorine dose over time and bacterial isolates were adequately exposed to reacting chlorine species during the disinfection process. Values obtained for disinfection exponent $n$ ranged between 1.57 and 22.43 while time exponent $\mathrm{m}$ had values of $-0.23-0.17$. For inactivation reactions with coefficient $n$ greater than 1 , the chlorine dose has a greater influence on bacterial inactivation than contact time [60]. These results suggest a greater impact of chlorine dose of $1.5 \mathrm{mg} / \mathrm{L}$ on bacterial inactivation than the effect of exposure time. A chlorine dose of $1.5 \mathrm{mg} / \mathrm{L}$ could serve as an alternative dose for control of $E$. coli and some bacteria species of public health concern in wastewater treatment plants which will ensure protection of the public and environmental health.

\section{Conclusions}

This study evaluated the efficacy of chlorine disinfectant in the inactivation of some E. coli isolates recovered from secondary effluent samples from the clarifier of two selected wastewater 
treatment plants in the Eastern Cape Province, South Africa. Treatment at $0.5 \mathrm{mg} / \mathrm{L}$ free chlorine was ineffective in eliminating bacteria isolates and the survival of $E$. coli demonstrated a high level of $E$. coli tolerance to chlorine in all the suspensions at the recommended dose of $0.5 \mathrm{mg} / \mathrm{L}$. Further treatment at higher chlorine concentrations was more effective in inactivating E. coli isolates and complete inactivation of E. coli population was achieved at optimum dose of $1.5 \mathrm{mg} / \mathrm{L}$. For optimization of disinfection processes, the chlorine dose required to achieve sufficient disinfection of wastewater appears to demand a review of current guidelines as observed for $0.5 \mathrm{mg} / \mathrm{L}$ free chlorine especially in resource-limited countries dependent on cost-effective and available disinfectant for wastewater treatment. These results demonstrate the potentials of $1.5 \mathrm{mg} / \mathrm{L}$ free chlorine obtained in this study as an effective dose to control E. coli tolerance in chlorinated effluents and is hereby proposed.

Acknowledgments: We are grateful to the South Africa Medical Research Council (SAMRC), the University of Fort Hare and Nigeria Tertiary Education Fund (TET Fund) for financial support.

Author Contributions: Anthony Okoh conceived the idea; Anthony Okoh, Mojisola Owoseni and Ademola Olaniran designed the experiments, Mojisola Owoseni performed the experiments, Mojisola Owoseni analyzed the data; Anthony Okoh and Ademola Olaniran contributed reagents/materials/analytical tools; Mojisola Owoseni wrote the paper; Anthony Okoh reviewed the paper.

Conflicts of Interest: The authors declare no conflict of interest. The funding sponsors had no role in the design of the study; in the collection, analyses and interpretation of data; in the writing of the manuscript, and in the decision to publish the results.

\section{References}

1. Levantesi, C.; La Mantia, R.; Masciopinto, C.; Böckelmann, U.; Ayuso-Gabella, M.N.; Salgot, M.; Tandoi, V.; Van Houtte, E. Quantification of pathogenic microorganisms and microbial indicators in three wastewater reclamation and managed aquifer recharge facilities in Europe. Sci. Total Environ. 2010, 408, 4923-4930. Available online: http:/ / www.ncbi.nlm.nih.gov/pubmed/20692684 (accessed on 24 May 2016). [CrossRef] [PubMed]

2. Suthar, S.; Sharma, J.; Chabukdhara, M.; Nema, A.K. Water quality assessment of river Hindon at Ghaziabad, India: Impact of industrial and urban wastewater. Environ Monit. 2010, 165, 103-112. [CrossRef] [PubMed]

3. Calijuri, M.L.; do Couto, E.D.A.; Santiago, A.D.F.; Camargo, R.D.A.; e Silva, M.D.F.M. Evaluation of the Influence of Natural and Antrhopogenic Processes on Water Quality in Karstic Region. Water Air Soil Pollut. 2011, 223, 2157-2168. [CrossRef]

4. Nontongana, N.; Sibanda, T.; Ngwenya, E.O.A. Prevalence and antibiogram profiling of Escherichia coli pathotypes isolated from the Kat River and the Fort Beaufort abstraction water. Int. J. Env. Res. Public Health 2014, 11, 8213-8227. [CrossRef] [PubMed]

5. Veschetti, E.; Cutilli, D.; Bonadonna, L.; Briancesco, R.; Martini, C.; Cecchini, G.; Anastasi, P.; Ottaviani, M. Pilot-plant comparative study of peracetic acid and sodium hypochlorite wastewater disinfection. Water. Res. 2003, 37, 78-94. [CrossRef]

6. Cho, M.; Kim, J.; Kim, J.Y.; Yoon, J.; Kim, J.H. Mechanisms of Escherichia coli inactivation by several disinfectants. Water. Res. 2010, 44, 3410-3418. Available online: http://www.ncbi.nlm.nih.gov/pubmed/ 20427068 (accessed on 24 May 2014). [CrossRef] [PubMed]

7. Zyara, A.M.; Torvinen, E.; Veijalainen, A.; Heinonen-tanski, H. The Effect of UV and Combined Chlorine/UV Treatment on Coliphages in Drinking. Water 2016, 8, 130. [CrossRef]

8. Lloyd's Register Group. Understanding Ballast Water Management Series; Lloyd's Register Group Limited: Southampton, UK, 2012.

9. Werschkun, B.; Sommer, Y.; Banerji, S. Disinfection by-products in ballast water treatment: An evaluation of regulatory data. Water Res. 2012, 46, 4884-4901. [CrossRef] [PubMed]

10. Zhong, X.; Cui, C.; Yu, S. Seasonal evaluation of disinfection by-products throughout two full-scale drinking water treatment plants. Chemosphere 2017, 179, 290-297. Available online: http:/ /www.sciencedirect.com/ science/article/pii/S0045653517304769 (accessed on 4 May 2017). [CrossRef] [PubMed]

11. Anastasi, E.M.; Wohlsen, T.D.; Stratton, H.M.; Katouli, M. Survival of Escherichia coli in two sewage treatment plants using UV irradiation and chlorination for disinfection. Water Res. 2013, 47, 6670-6679. [CrossRef] [PubMed] 
12. Chawla, S.; Parashar, R.; Parashar, R. Is estimation of residual free chlorine in water by drop number titration method reliable? Investigation of statistical, pragmatic, psychological and philosophical reasons. Int. J. Chem. Pharm. Rev. Res. 2015, 2, 11-18.

13. Chiang, P.; Chang, E.; Chuang, C.; Liang, C.; Huang, C. Evaluating and elucidating the formation of nitrogen-contained disinfection by-products during pre-ozonation and chlorination. Chemosphere 2010, 80, 327-330. [CrossRef] [PubMed]

14. Abdel-Raouf, N. Microalgae and wastewater treatment. Saudi J. Biol. Sci. 2012, 19, 257-275. [CrossRef] [PubMed]

15. Amin, M.; Hashemi, H.; Bovini, A.; Hung, Y. A review on wastewater disinfection. Int. J. Environ. Health Eng. 2013, 2, 22.

16. Schwering, M.; Song, J.; Louie, M.; Turner, R.J.; Ceri, H. Multi-species biofilms defined from drinking water microorganisms provide increased protection against chlorine disinfection. Biofouling 2013, 29, 917-928. Available online: http:/ / www.ncbi.nlm.nih.gov/pubmed/23879183 (accessed on 28 June 2016). [CrossRef] [PubMed]

17. Kekeç, Ö.; Gökalsın, B.; Karaltı, İ.; Kayhan, F.E.; Sesal, N.C. Effects of Chlorine Stress on Pseudomonas aeruginosa Biofilm and Analysis of Related Gene Expressions. Curr. Microbiol. 2016, 73, 228-235. [CrossRef] [PubMed]

18. Owoseni, M.; Okoh, A. Evidence of emerging challenge of chlorine tolerance of Enterococcus species recovered from wastewater treatment plants. Int. Biodeterior. Biodegrad. 2017, 120, 216-223. Available online: http: / /linkinghub.elsevier.com/retrieve/pii/S0964830516306813 (accessed on 5 April 2017). [CrossRef]

19. Owoseni, M.; Okoh, A. Assessment of chlorine tolerance profile of Citrobacter species recovered from wastewater treatment plants in Eastern Cape, South Africa. Environ. Monit. Assess. 2017, 189, 1-12. Available online: http://linkinghub.elsevier.com/retrieve/pii/S0964830516306813 (accessed on 5 April 2017). [CrossRef] [PubMed]

20. LeChevallier, M.; Kwok-Keung, A. World Health Organization: Water treatment and Pathogen Control: Process Efficiency in Achieving Safe Drinking Water; IWA Publishing: London, UK, 2014; pp. 1-176.

21. Environmental Protection Agency. EPA Water Treatment Manual: Disinfection; EPA: Wexford, Ireland, 2011; Available online: https:/ / www.epa.ie/pubs/advice/drinkingwater/Disinfection2_web.pdf (accessed on 5 June 2015).

22. Ma, X.; Bibby, K. Free chlorine and monochloramine inactivation kinetics of Aspergillus and Penicillium in drinking water. Water Res. 2017. Available online: http://linkinghub.elsevier.com/retrieve/pii/ S0043135417303329 (accessed on 10 April 2017).

23. Li, D.; Zeng, S.; Gu, A.Z.; He, M.; Shi, H. Inactivation, reactivation and regrowth of indigenous bacteria in reclaimed water after chlorine disinfection of a municipal wastewater treatment plant. J. Environ. Sci. (China) 2013, 25, 1319-1325. [CrossRef]

24. Mounaouer, B.; Olfa, F.; Abdennaceur, H. Disinfection of wastewater by infiltration-percolation coupled to UV irradiation in an arid Tunisian area. Hydrol. Current Res. 2013, 4, 155. [CrossRef]

25. Department of Water Affairs. Revision of General authorisations in Terms of Section 39 of The National water Act, (Act No. 36 of 1998) (The Act). 2013, pp. 3-32. Available online: https//www.faolex.fao.org/ docs/pdf/saf126916.pdf (accessed on 20 December 2016).

26. Wang, S.; Deng, K.; Zaremba, S.; Deng, X.; Lin, C.; Wang, Q.; Totorello, M.L.; Zhang, W. Transcriptomic response of Escherichia coli O157:H7 to oxidative stress. Appl. Environ. Microbiol. 2009, 75, 6110-6123. Available online: http:/ / www.pubmedcentral.nih.gov / articlerender.fcgi?artid=2753066\&tool=pmcentrez\& rendertype $=$ abstract (accessed on 5 June 2014). [CrossRef] [PubMed]

27. Rice, E.W.; Clark, R.M.; Johnson, C.H. Chlorine inactivation of Escherichia coli O157:H7. Emerg. Infect. Dis. 1999, 5, 461-463. [CrossRef] [PubMed]

28. Helbling, D.E.; Vanbriesen, J.M. Free chlorine demand and cell survival of microbial suspensions. Water Res. 2007, 41, 4424-4434. Available online: http://www.ncbi.nlm.nih.gov/pubmed/17624396 (accessed on 5 June 2014). [CrossRef] [PubMed]

29. Zhou, B.; Luo, Y.; Nou, X.; Lyu, S.; Wang, Q. Inactivation dynamics of Salmonella enterica, Listeria monocytogenes, and Escherichia coli O157:H7 in wash water during simulated chlorine depletion and replenishment processes. Food Microbiol. 2015, 50, 88-96. [CrossRef] [PubMed] 
30. Coronel-Olivares, C.; Reyes-Gómez, L.M.; Hernández-Muñoz, A.; Martínez-Falcón, A.P.; Vázquez-Rodríguez, G.A.; Iturbe, U. Chlorine disinfection of Pseudomonas aeruginosa, total coliforms, Escherichia coli and Enterococcus faecalis: Revisiting reclaimed water regulations. Water Sci. Technol. 2011, 64, 2151-2157. Available online: http:/ / www.ncbi.nlm.nih.gov/pubmed/22156117 (accessed on 26 December 2016). [CrossRef] [PubMed]

31. Huang, J.J.; Hu, H.Y.; Wu, Y.H.; Wei, B.; Lu, Y. Effect of chlorination and 26 May 2014 disinfection on tetA-mediated tetracycline resistance of Escherichia coli. Chemosphere 2013, 90, 2247-2253. Available online: http:/ / www.ncbi.nlm.nih.gov/pubmed/23123077 (accessed on 10 December 2016). [CrossRef] [PubMed]

32. Pang, Y.; Huang, J.; Xi, J.; Hu, H.; Zhu, Y. Effect of ultraviolet irradiation and chlorination on ampicillin-resistant Escherichia coli and its ampicillin resistance gene. Front. Environ. Sci. Eng. 2016, 10, 522-530. [CrossRef]

33. Momba, M.N.B.; Sibewu, M.; Mandeya, A. Survival of somatic and F-RNA coliphages in treated wastewater effluents and their impact on viral quality of the receiving water bodies in the Eastern Cape Province-South Africa. J. Biol. Sci. 2009, 9, 648-654. [CrossRef]

34. Samie, A.; Obi, C.L.; Igumbor, J.O.; Momba, M.N.B. Focus on 14 sewage treatment plants in the Mpumalanga Province, South Africa in order to gauge the efficiency of wastewater treatment. Afr. J. Biotechnol. 2009, 8, 3276-3285. Available online: http://www.academicjournals.org/AJB/PDF/pdf2009/ (accessed on 6 October 2016).

35. Teklehaimanot, G.Z.; Coetzee, M.A.A.; Momba, M.N.B. Faecal pollution loads in the wastewater effluents and receiving water bodies: A potential threat to the health of Sedibeng and Soshanguve communities, South Africa. Environ. Sci. Pollut. Res. 2014, 21, 9589-9603. [CrossRef] [PubMed]

36. Osuolale, O.; Okoh, A. Assessment of the Physicochemical Qualities and Prevalence of Escherichia coli and Vibrios in the Final Effluents of Two Wastewater Treatment Plants in South Africa: Ecological and Public Health Implications. Int. J. Environ. Res. Public Health 2015, 12, 13399-13412. Available online: http:/ / www.mdpi.com/1660-4601/12/10/13399/ (accessed on 7 October 2016). [CrossRef] [PubMed]

37. Department of Water Affairs. South African Water Quality Guidelines Volume 1 Domestic Use. 1996. Available online: http:/ / www.dwa.gov.za/iwqs/wq_guide/Pol_saWQguideFRESHDomesticusevol1.pdf (accessed on 29 December 2014).

38. APHA; AWWA; WEF. Standard Methods for the Examination of Water and Wastewater. 1999, p. 1496. Available online: https:/ / www.standardmethods.org (accessed on 12 December 2016).

39. Lopez-Saucedo, C.; Cerna, J.F.; Villegas-Sepulveda, N.; Thompson, R.; Velazquez, F.R.; Torres, J.; Tarr, P.I.; Estrada-Garcia, T. Polymerase Chain Reaction To Detect Diverse Loci Associated with Escherichia coli. Emerg. Infect. Dis. 2003, 9, 127-131. [CrossRef] [PubMed]

40. Maugeri, T.L.; Carbone, M.; Fera, M.T.; Irrera, G.P.; Gugliandolo, C. Distribution of potentially pathogenic bacteria as free living and plankton associated in a marine coastal zone. J. Appl. Microbiol. 2004, 97, 354-361. [CrossRef] [PubMed]

41. Tsai, Y.; Palmer, C.J.; Sangermano, L.R. Detection of Escherichia coli in Sewage and Sludge by Polymerase Chain Reaction. Appl. Environ. Microbiol. 1993, 59, 353-357. [PubMed]

42. Lin, Y.; Li, D.; Gu, A.Z.; Zeng, S.; He, M. Bacterial regrowth in water reclamation and distribution systems revealed by viable bacterial detection assays. Chemosphere 2016, 144, 2165-2174. [CrossRef] [PubMed]

43. Watson, H.E. A note on the variation of the rate of disinfection with change in the concentration of the disinfectant. Epidemiol. Infect. 1908, 8, 536-542. [CrossRef]

44. Hom, L.W. Kinetics of chlorine disinfection in an ecosystem. J. Environ. Eng. 1972, 98, 183-194.

45. Dungeni, M.; Van der Merwe, R.; Momba, M. Abundance of pathogenic bacteria and viral indicators in chlorinated effluents produced by four wastewater treatment plants in the Gauteng Province, South Africa. Water Res. 2010, 36, 607-614. [CrossRef]

46. World Health Organization. Guidelines for Drinking Water Quality; WHO: Geneva, Switzerland, 2004.

47. Akhtar, M.; Maserati, A.; Diez-Gonzalez, F.; Sampedro, F. Does antibiotic resistance influence shiga-toxigenic Escherichia coli $\mathrm{O} 26$ and $\mathrm{O} 103$ survival to stress environments? Food Control. 2016, 68, 330-336. Available online: http:/ /linkinghub.elsevier.com/retrieve/pii/S0956713516301803 (accessed on 16 February 2017). [CrossRef]

48. Park, H.; Hung, Y.C.; Chung, D. Effects of chlorine and pH on efficacy of electrolyzed water for inactivating Escherichia coli O157:H7 and Listeria monocytogenes. Int. J. Food Microbiol. 2004, 91, 13-18. 
49. Gillespie, S.; Lipphaus, P.; Green, J.; Parsons, S.; Weir, P.; Juskowiak, K.; Jefferson, B.; Jarvis, P.; Nocker, A. Assessing microbiological water quality in drinking water distribution systems with disinfectant residual using flow cytometry. Water Res. 2014, 65, 224-234. [CrossRef] [PubMed]

50. Koivunen, J.; Heinonen-Tanski, H. Inactivation of enteric microorganisms with chemical disinfectants, UV irradiation and combined chemical/UV treatments. Water Res. 2005, 39, 1519-1526. Available online: http:/ / www.ncbi.nlm.nih.gov/pubmed/15878023 (accessed on 5 June 2014). [CrossRef] [PubMed]

51. Khan, S.; Beattie, T.K.; Knapp, C.W. Relationship between antibiotic- and disinfectant-resistance profiles in bacteria harvested from tap water. Chemosphere 2016, 152, 132-141. Available online: http:/ / www.scopus. com/inward/record.url?eid=2-s2.0-84960096633\&partnerID=tZOtx3y1 (accessed on 10 December 2016). [CrossRef] [PubMed]

52. Pereira, V.J.; Marques, R.; Marques, M.; Benoliel, M.J.; Crespo, M.T.B. Free chlorine inactivation of fungi in drinking water sources. Water Res. 2013, 47, 517-523. [CrossRef] [PubMed]

53. Winward, G.P.; Avery, L.M.; Stephenson, T.; Jefferson, B. Chlorine disinfection of grey water for reuse: effect of organics and particles. Water Res. 2008, 42, 483-491. Available online: http:/ / www.ncbi.nlm.nih.gov/ pubmed/17904612 (accessed on June 3 2014). [CrossRef] [PubMed]

54. Van Haute, S.; Sampers, I.; Holvoet, K.; Uyttendaelea, M. Physicochemical quality and chemical safety of chlorine as a reconditioning agent and wash water disinfectant for fresh-cut lettuce washing. Appl. Environ. Microbiol. 2013, 79, 2850-2861. [CrossRef] [PubMed]

55. Valero, P.; Mosteo, R.; Ormad., M.P.; Lázaro, L.; Ovelleiro, J.L. Inactivation of Enterococcus sp. by conventional and advanced oxidation processes in synthetic treated urban wastewater. Ozone Sci. Eng. 2015. [CrossRef]

56. Zhao, T.; Doyle, M.P.; Zhao, P.; Blake, P.; Wu, F.M. Chlorine inactivation of Escherichia coli O157:H7 in water. J. Food Prot. 2001, 64, 1607-1609. [CrossRef] [PubMed]

57. Mir, J.; Morato, J.; Ribas, F. Resistance to chlorine of freshwater bacterial strains. J. Appl. Microbiol. 1997, 82, 7-18. [CrossRef] [PubMed]

58. Berry, D.; Xi, C.; Raskin, L. Effect of Growth Conditions on Inactivation of Escherichia coli with Monochloramine. Environ. Sci. Technol. 2009, 43, 884-889. [CrossRef] [PubMed]

59. Cherchi, C.; Gu, A.Z. Effect of bacterial growth stage on resistane to chlorine disinfection. Water Sci. Technol. 2011, 64, 7-13. [CrossRef] [PubMed]

60. Mounaouer, B.; Abdennaceur, H. Modeling and kinetic characterization of wastewater disinfection using chlorine and UV irradiation. Environ. Sci. Pollut. Res. 2016, 23, 19861-19875. [CrossRef] [PubMed] 